\title{
Subtalar arthroscopic debridment for the treatment of sinus tarsi syndrome: case series
}

(D) Nacime Salomão Barbachan Mansur ${ }^{1}$

(iD) Tiago Soares Baumfeld ${ }^{1}$

DAndré Vitor Kerber Cavalcante Lemos ${ }^{1}$

(iD) Rafael Mohriak de Azevedo'

(iD) Lucas Furtado da Fonseca ${ }^{1}$

(iD) Juliana Doering ${ }^{1}$

(D) Caio Augusto Souza Nery ${ }^{1}$

1. Department of Orthopedics and Traumatology, Escola Paulista de Medicina, Federal University of São Paulo, SP, Brasil

http://dx.doi.org/10.1590/1806-9282.65.3.370

\section{SUMMARY}

OBJECTIVE: The objective of this study is to report the results of arthroscopic debridement of the subtalar joint in eight patients with Sinus Tarsi Syndrome (STS) refractory to conservative treatment.

METHODS: This is a retrospective study of eight patients with STS who underwent subtalar arthroscopy for debridement of the sinus tarsi between January 2015 and January 2017 after six months of conservative treatment. All patients answered an epidemiological questionnaire and underwent functional evaluation with the Visual Analogue Pain Scale (VAS) and the American Orthopedic Foot and Ankle Society Score (AOFAS) in the preoperative and in the last evaluation (average of 12 months - 6-24 months).

RESULTS: All patients showed severe synovitis in the region. Seven patients had remnants of the talocalcaneal ligaments and six of the cervical ligament. AOFAS increased by 30 points on average (51.75 in the preoperative period to 82.62 in the last follow-up) and the VAS decreased on average by 5 points (7.37 preoperatively to 2.12 in the last follow-up). These results were statistically significant with $p=0.043$ and $p=0.032$ respectively. Six patients described the result as excellent and two as good. No complications were reported. All patients returned to sports after six months of follow-up.

CONCLUSION: The arthroscopic debridement of the subtalar joint is an effective and safe alternative in the treatment of STS refractory to conservative treatment. More studies, with a prospective methodology, are necessary to prove the results of this technique.

KEYWORDS: Arthroscopy/methods. Tarsal bones. Subtalar joint. Debridement.

\section{INTRODUCTION}

The tarsal sinus syndrome (TSS) can be understood as a set of conditions that affect this topography and produce similar signs and symptoms. Even though its incidence is not reported to be high, it often causes pain and permanent disability, likely re- moving affected individuals from their activities for long periods. In this syndrome, the presence of pain within the tarsal sinus, which worsens with deep palpation, may be accompanied by local edema and sense of instability ${ }^{1-3}$. 
The etiology of OSH is often undefined. However, the presence of previous trauma can be found in approximately $70 \%$ of the cases ${ }^{1.4}$. Inversion sprains, fractures, and repetitive traumas are pointed out as responsible for injuries of the talocalcaneal ligaments that, when poorly healed, could produce a subtalar instability, a finding usually associated with the syndrome ${ }^{1,4-6}$.

Ligament remnants and the presence of joint lassitude cause synovitis and chronic local irritation that translates to the patient as local pain and discomfort $^{7.8}$. The initial treatment is based on motor physical therapy and on the use of semi-rigid orthoses, which reduce the mobility of the area ${ }^{3,4,6}$.

In the failure of a non-surgical approach, the arthroscopic debridement is a viable alternative with high rates of positive outcomes. ${ }^{1,2,4,5,9}$ The technique is performed using two portals anterior to the lateral malleolus, seeking visualization and resection of the ligament debris, as well as of the hyperplastic synovial tissue.

The association of the subtalar instability with the TSS has led some authors to propose adjuvant stabilizing procedures for this region. These approaches include from a simple Brostrom-Gould ligamentoplasty to reconstructions with free grafts and talocalcaneal arthrodesis. Despite the few series of cases, the techniques have shown consistent and lasting results $6,10,11$.

The objective of this study is to report the results of subtalar arthroscopic debridement in eight patients with TSS resistant to conservative treatment.

\section{METHODS}

This is a retrospective study with eight TSS patients who underwent subtalar arthroscopy for debridement of the tarsal sinus between January 2015 and January 2017. Four men and four women, with an average age of 43 years (33-57 years), were diagnosed with TSS for reporting pain on the tarsal sinus, exacerbated by deep palpation and mobilization of the subtalar. All patients were submitted to x-rays with foot and ankle load, which showed an absence of degenerative diseases, in addition to an evaluation by magnetic resonance imaging, which showed an increase of signal in the area and/or the presence of talocalcaneal ligament injuries. None of the patients presented sequels from fractures, osteoarthritis or tarsal coalition. Only after six months of conserva-

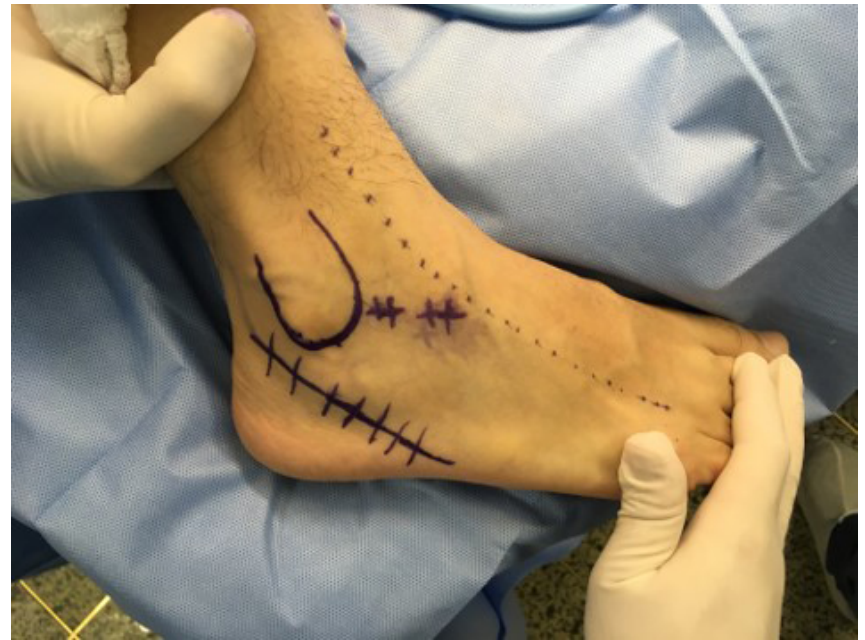

FIGURE 1. DEMARCATION OF THE ARTHROSCOPIC PORTALS.

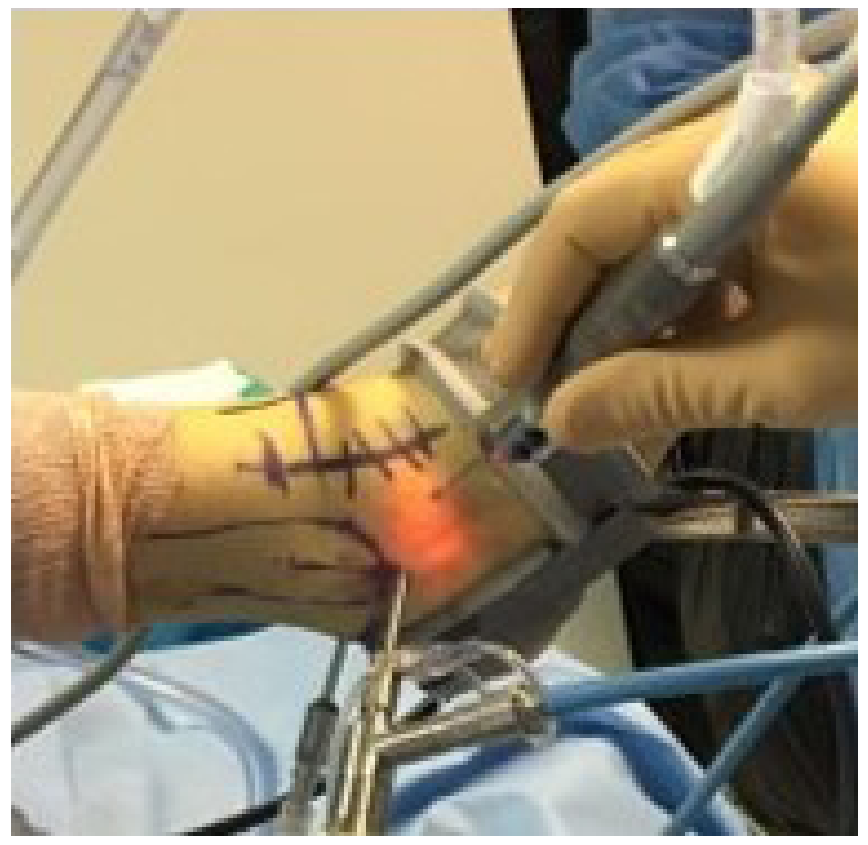

FIGURE 2. ARTHROSCOPIC TRIANGULATION.

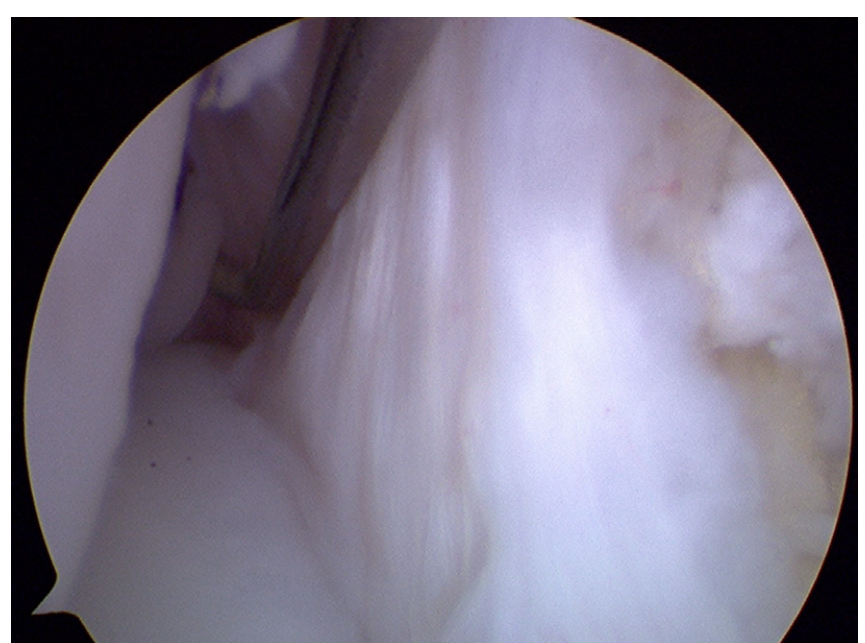

FIGURE 3. ARTHROSCOPIC IMAGE SHOWING REMNANTS OF INTEROSSEOUS LIGAMENTS AND LATERAL TALOCALCANEAL AND INTENSE LOCAL SYNOVITIS. 
tive treatment, including rest, analgesic and anti-inflammatory medication, muscle strengthening, and use of semi-rigid orthosis, surgical treatment was indicated.

After approval by the ethics committee of the institution and the signature of the informed consent term, all patients filled out the epidemiological questionnaire and underwent functional assessment using the Visual Analog Scale for pain (VAS) and the American Orthopaedic Foot and Ankle Society Score (Aofas) in the preoperative consultation and during follow-up, with an average of 12 months (6-24 months).

The statistical analysis was performed with the Gretl (2017c) software. Student t-test was used to compare pre-operative and post-operative data. In this study, we adopted a 0.05 value for the alpha error and consequent rejection of the null hypothesis.

\section{SURGICAL TECHNIQUE}

The patients underwent general anesthesia associated with the blocking of the saphenous and femoral nerves. After positioning the patients on dorsal decubitus with a small cushion under the gluteus and pneumatic tourniquet on the thigh, they were all marked for the arthroscopic portals and the local anatomical references (Figure 1).

The intermediary portal was established at $1 \mathrm{~cm}$ from the anterior edge of the lateral malleolus, at the height of its apex, directly on the tarsal sinus. The anterolateral portal was performed $1 \mathrm{~cm}$ distal and $3 \mathrm{~cm}$ above the apex of the fibula ${ }^{12}$. Skin incisions, transverse, with an 11 blade, were made in the places previously established, followed by the introduction of a gripper for opening the capsule. The arthroscopy was performed with a $4.5 \mathrm{~mm}$ and $30^{\circ}$ lens, instrumented by a shaver and $4.5 \mathrm{~mm}$ grippers (Figure 2). An electrocoagulation tip of the same size was also used. The resection of the synovitis and the hypertrophic ligament remains was performed, switching the portal and visualization used whenever necessary. The procedure was successful and finalized after verification of complete cleaning of the cavity and the absence of impact of soft parts to the movement of the subtalar (Figure 3).

After the suture, a sterile bandage was applied, followed by a splint. In the first postoperative follow up, after one week, the bandage was replaced, and the splint substituted by an immobilizing boot. Physical therapy started on the same week, stimulating the mobility of the ankle and subtalar in a controlled

TABLE 1. PATIENTS' DESCRIPTIVE DATA

\begin{tabular}{|c|c|c|c|c|c|c|c|c|c|c|}
\hline $\begin{array}{l}\text { Patient } \\
\text { no. }\end{array}$ & Side & Age & Gender & $\begin{array}{l}\text { Aofas } \\
\text { Pre }\end{array}$ & $\begin{array}{l}\text { Aofas } \\
\text { Post }\end{array}$ & $\begin{array}{l}\text { Eva } \\
\text { Pre }\end{array}$ & $\begin{array}{l}\text { Eva } \\
\text { Post }\end{array}$ & $\begin{array}{l}\text { Follow-up } \\
\text { (Months) }\end{array}$ & Diagnosis & Procedure \\
\hline 1 & $E$ & 55 & $M$ & 58 & 69 & 9 & 4 & 8 & $\begin{array}{l}\text { TSS + Ankle later- } \\
\text { al instability }\end{array}$ & $\begin{array}{l}\text { Subtalar arthros- } \\
\text { copy + Bros- } \\
\text { trom-Gould }\end{array}$ \\
\hline 2 & $E$ & 52 & $\mathrm{~F}$ & 68 & 90 & 5 & 1 & 6 & TSS & $\begin{array}{l}\text { Subtalar arthros- } \\
\text { copy }\end{array}$ \\
\hline 3 & $E$ & 57 & $\mathrm{~F}$ & 32 & 69 & 7 & 4 & 12 & $\begin{array}{l}\text { TSS + Ankle } \\
\text { lateral instability + } \\
\text { Pes cavus }\end{array}$ & $\begin{array}{l}\text { Subtalar arthros- } \\
\text { copy + Bros- } \\
\text { trom-Gould + } \\
\text { Dwyer }\end{array}$ \\
\hline 4 & $D$ & 33 & $M$ & 71 & 84 & 8 & 2 & 24 & $\begin{array}{l}\text { TSS + Ankle } \\
\text { lateral instability + } \\
\text { Pes cavus }\end{array}$ & $\begin{array}{l}\text { Subtalar arthros- } \\
\text { copy }+ \text { Bros- } \\
\text { trom-Gould + } \\
\text { Dwyer }\end{array}$ \\
\hline 5 & $E$ & 35 & $\mathrm{~F}$ & 32 & 69 & 9 & 3 & 10 & $\begin{array}{l}\text { TSS + Ankle later- } \\
\text { al instability }\end{array}$ & $\begin{array}{l}\text { Subtalar arthros- } \\
\text { copy + Bros- } \\
\text { trom-Gould }\end{array}$ \\
\hline 6 & $D$ & 37 & $M$ & 76 & 90 & 7 & 1 & 12 & $\begin{array}{l}\text { TSS + Ankle later- } \\
\text { al instability }\end{array}$ & $\begin{array}{l}\text { Subtalar arthros- } \\
\text { copy + Bros- } \\
\text { trom-Gould }\end{array}$ \\
\hline 7 & $D$ & 37 & $\mathrm{~F}$ & 33 & 90 & 6 & 1 & 7 & $\begin{array}{l}\text { TSS + Ankle later- } \\
\text { al instability }\end{array}$ & $\begin{array}{l}\text { Subtalar arthros- } \\
\text { copy + Bros- } \\
\text { trom-Gould }\end{array}$ \\
\hline 8 & $D$ & 40 & $M$ & 44 & 100 & 8 & 1 & 18 & TSS & $\begin{array}{l}\text { Subtalar arthros- } \\
\text { copy }\end{array}$ \\
\hline Average & & 43.25 & & 51.75 & 82.62 & 7.37 & 2.12 & 12.12 & & \\
\hline
\end{tabular}


way, avoiding the inversion and internal rotation up to the sixth week. The load was initiated during the first week progressively. The boot was replaced by a rigid anklet on the fourth week, and light physical activities were initiated. The patients were allowed to resume sporting activities at the 16th week.

\section{RESULTS}

All eight patients reported a previous history of trauma in the ankle region, seven of them by inversion sprains and one by nonspecific trauma. The descriptive data of the patients can be found in Table 1. It is worth noting that only two patients presented isolated tarsal sinus syndrome and received arthroscopic debridement of the subtalar as an isolated intervention. The other four had lateral instability of the ankle and two, in addition to the instability, also had associated rearfoot varus. In the patients who had instability, Brostrom-Gould ligamentoplasty was performed (which also allowed for the stabilization of the subtalar), and, in patients with rearfoot varus, Dwyer osteotomy of the calcaneus was performed.

During the subtalar arthroscopy, all patients showed exuberant synovitis in the region. Seven patients had remnants of talocalcaneal ligaments and six of the cervical ligament. No cartilage or tumoral lesion was found.

Regarding the scores measured, the Aofas increased by 30 points on average ( 51.75 at the preoperative to 82.62 at the last follow-up) and VAS decreased on average 5 points ( 7.37 at the preoperative to 2.12 at the last follow-up) during the evolution. These results were statistically significant, with $p=0.043$ and $p=$ 0.032 , respectively. Six patients described the result as excellent and two as good. No complication was reported. All patients resumed sporting activities after six months of follow-up.

\section{DISCUSSION}

Nonspecific complaints of pain in the lateral region of the ankle motivate a good number of athletes and sedentary patients to seek medical care. Among the differential diagnoses possible, TSS stands out. It is a condition common in the region that causes pain and is often not diagnosed and poorly treated. This condition is characterized by pain on the tarsal sinus, commonly associated with a previous traumatic episode or instability of the ankle and subtalar ${ }^{13.14}$.

Pathology anatomy studies prove the presence of intense inflammatory infiltration in the tarsal sinus, associated with the presence of chronic synovitis and disorganized ligament remnants ${ }^{7.8}$. These findings support the theory of previous trauma (acute or repetition) as the primary etiologic factor in the pathogenesis of this disease. All patients in our study also presented a history of previous trauma, corroborating the data in the literature.

Initially, the approach used in these individuals is non-operative, comprising of a resting phase, muscle strengthening, analgesia, and functional immobilization $^{3}$. Some authors consider the infiltration of the tarsus with corticosteroids an alternative for resistant cases ${ }^{1.2}$. The failure of these measures, however, requires surgical resolution, which can be performed using an open approach or endoscopy.

Frey et al. ${ }^{5}$ described the results of the arthroscopic treatment of TSS in 49 cases. With an average follow-up of seven years, they found a rate of satisfaction of $94 \%$. The author reported only five minor complications; the most common of them was the transient neuropraxia of the superficial fibular nerve. Among the injuries observed during the arthroscopy, the most prevalent was the rupture of the interosseous ligament ${ }^{5}$. Oloff et al. ${ }^{2}$, in turn, reported good results using the same technique, with an average Aofas of 85 at the last follow-up. Of the 29 patients in their series, only one was subjected to a secondary to arthrofibrosis arthrotomy. No complications were reported 2. Lee et al. ${ }^{1}$ demonstrated the results of arthroscopy in 31 patients (33 feet) with a follow-up of 24 months. The VAS of these patients showed an average improvement of 7.3 to 2.7 , and the average trend of the Aofas went from 43.1 to 86.2. Only one patient progressed with irritation of the superficial fibular nerve, showing complete resolution after a neurolysis procedure ${ }^{1}$.

This study is in agreement with the positive results presented in the literature. Our patients reported a high rate of satisfaction, $75 \%$ considered them excellent, and two results were considered good. We also had high rates of pain reduction, with an average VAS reduction from 7.37 at the preoperative to 2.12 at the last follow-up. The Aofas, in turn, increased from 51.75 at the preoperative to 82.62 at the last follow-up. These results, with statistical significance, were similar to those pre- 
viously observed ${ }^{1,2,5}$ and proved the effectiveness of the subtalar arthroscopy for treating resistant TSS. In addition, no complications were observed in this study, which demonstrates the safety of the technique.

We believe that the arthroscopic debridement of the subtalar is a viable alternative and a reproducible method for the treatment of TSS irresponsive to the conservative treatment. This study is relevant because it deals with a topic of sparse description in the literature and details the results with objective parameters for evaluation. The disadvantages of this study are its retrospective methodology, low number of patients, and the presence of associated conditions and adjuvant procedures that carry biases to the interpretation of the data.

\section{CONCLUSIONS}

Arthroscopic debridement of the subtalar is a safe and effective alternative for the treatment of TSS resistant to conservative treatment. Further studies with a prospective methodology are needed to confirm the results of the technique.

\section{Conflict of interest}

The authors declare that there are no conflicts of interest.

\section{RESUMO}

OBJETIVO: O objetivo desse estudo é relatar os resultados do desbridamento artroscópico da subtalar em oito pacientes portadores da Síndrome do Seio do Tarso (SST) refratária ao tratamento conservador.

MÉTODOS: Este é um estudo retrospectivo com oito pacientes com diagnóstico de STT que foram submetidos à artroscopia subtalar para desbridamento do seio do tarso entre janeiro de 2015 e janeiro de 2017, após seis meses de tratamento conservador. Todos os pacientes responderam questionário epidemiológico e foram submetidos à avaliação funcional com a Escala Visual Analógica de dor (EVA) e o American Orthopaedic Foot and Ankle Society Score (Aofas) no pré-operatório e na última avaliação, em uma média de 12 meses (6-24 meses).

RESULTADOS: Todos os pacientes exibiram intensa sinovite na região. Sete pacientes tinham resquícios de ligamentos talocalcaneanos e seis do ligamento cervical. O Aofas aumentou 30 pontos em média (51,75 no pré-operatório para 82,62 no último seguimento) e a EVA diminuiu em média 5 pontos (7,37 no pré-operatório para 2,12 no último seguimento). Esses resultados foram estatisticamente significativos com $p=0,043$ e $p=0,032$, respectivamente. Seis pacientes descreveram o resultado como excelente e dois como bom. Nenhuma complicação foi relatada. Todos os pacientes retornaram ao esporte após seis meses de acompanhamento.

CONCLUSÃO: O desbridamento artroscópico da subtalar é uma alternativa eficaz e segura no tratamento da SST refratária ao tratamento conservador. Mais estudos, com metodologia prospectiva, são necessários para comprovar os resultados da técnica.

PALAVRAS-CHAVE: Artroscopia/métodos. Ossos do tarso. Articulação talocalcânea. Desbridamento.

\section{REFERENCES}

1. Lee KB, Bai LB, Song EK, Jung ST, Kong IK. Subtalar arthroscopy for sinus tarsi syndrome: arthroscopic findings and clinical outcomes of 33 consecutive cases. Arthroscopy. 2008;24(10):1130-4.

2. Oloff $L M$, Schulhofer $S D$, Bocko AP. Subtalar joint arthroscopy for sinus tarsi syndrome: a review of 29 cases. J Foot Ankle Surg. 2001;40(18):152-7.

3. Helgeson K. Examination and intervention for sinus tarsi syndrome. N Am J Sports Phys Ther. 2009;4(1):29-37.

4. Pisani G, Pisani PC, Parino E. Sinus tarsi syndrome and subtalar joint instability. Clin Podiatr Med Surg. 2005;22(1):63-77.

5. Frey $\mathrm{C}$, Feder KS, DiGiovanni C. Arthroscopic evaluation of the subtalar joint: does sinus tarsi syndrome exist? Foot Ankle Int. 1999;20(3):185-91.

6. Mittlmeier T, Wichelhaus A. Subtalar joint instability. Eur J Trauma Emerg Surg. 2015;41(6):623-9.

7. Akiyama K, Takakura Y, Tomita Y, Sugimoto K, Tanaka Y, Tamai S. Neurohistology of the sinus tarsi and sinus tarsi syndrome. J Orthop Sci. 1999;4(4):299-303.

8. Rein S, Manthey S, Zwipp H, Witt A. Distribution of sensory nerve endings around the human sinus tarsi: a cadaver study. J Anat. 2014;224(4):499508.

9. Muñoz G, Eckholt S. Subtalar arthroscopy: indications, technique and results. Foot Ankle Clin. 2015;20(1):93-108.

10. Aynardi M, Pedowitz DI, Raikin SM. Subtalar instability. Foot Ankle Clin. 2015;20(2):243-52.

11. Jung HG, Park JT, Shin MH, Lee SH, Eom IS, Lee DO. Outcome of subtalar instability reconstruction using the semitendinosus allograft tendon and biotenodesis screws. Knee Surg Sport Traumatol Arthrosc. 2015;23(8):2376-83

12. Beimers L, Frey C, van Dijk CN. Arthroscopy of the posterior subtalar joint. Foot Ankle Clin. 2006;11(2):369-90.

13. Maceira E, Monteagudo M. Subtalar anatomy and mechanics. Foot Ankle Clin. 2015;20(2):195-221.

14. Choudhary S, McNally E. Review of common and unusual causes of lateral ankle pain. Skeletal Radiol. 2011;40(11):1399-413. 
Erratum

http://dx.doi.org/10.1590/1806-9282.65.5.739

Regarding the article "Subtar arthroscopic debridment for the treatment of sinus tarsi syndrome: case series", with DOI number: http://dx.doi.org/10.1590/1806-9282.65.3.370, published in Journal of the Brazilian Medical Association, 2019;65;03, page 370:

Where was written: "Subtar arthroscopic debridment"

Now Read: "Subtalar arthroscopic debridment" 